11 | 2007

Varia

\title{
Igé, chapelle de Domange (Saône-et-Loire)
}

\section{Christian Sapin}

\section{(2) OpenEdition}

\section{Journals}

\section{Édition électronique}

URL : https://journals.openedition.org/cem/1902

DOI : $10.4000 /$ cem. 1902

ISSN : 1954-3093

\section{Éditeur}

Centre d'études médiévales Saint-Germain d'Auxerre

\section{Édition imprimée}

Date de publication : 15 août 2007

ISSN : 1623-5770

\section{Référence électronique}

Christian Sapin, «Igé, chapelle de Domange (Saône-et-Loire) », Bulletin du centre d'études médiévales d'Auxerre | BUCEMA [En ligne], 11 | 2007, mis en ligne le 22 juin 2007, consulté le 22 septembre 2022. URL : http://journals.openedition.org/cem/1902 ; DOI : https://doi.org/10.4000/cem.1902

Ce document a été généré automatiquement le 22 septembre 2022.

\section{(c) (i) (2)(2)}

Creative Commons - Attribution - Pas d'Utilisation Commerciale - Partage dans les Mêmes Conditions 4.0 International - CC BY-NC-SA 4.0

https://creativecommons.org/licenses/by-nc-sa/4.0/ 


\title{
Igé, chapelle de Domange (Saône-et- Loire)
}

\author{
Christian Sapin
}

1 La petite église de Domange sur la commune d'Igé, citée plusieurs fois dans les sources textuelles du $X^{\mathrm{e}}$ siècle (953, désignée capella en 962), conserve aujourd'hui une nef unique et un chevet dont la datation n'avait jamais jusqu'à présent été précisée. À l'occasion des sondages diagnostics préalables à la pose d'un drain, en collaboration avec l'INRAP (convention CNRS-INRAP), Emmanuel Laborier et Christian Sapin ont pu faire un certain nombre de constatations sur les différents états de la construction. Il s'agissait d'évaluer au départ les risques archéologiques aux abords immédiats de l'édifice; les sépultures étaient quasi inexistantes à cet endroit, et les fondations réduites à quatre ou cinq assises. Il existe peu de différence entre la nef charpentée et le chevet voûté. C'est plus dans la mise en œuvre, les élévations et leurs ouvertures que l'on a observé des changements. Il en résulte que la nef et l'avant-chœur pourraient être placés assez tôt (peut-être dès le $\mathrm{X}^{\mathrm{e}}$ siècle pour une partie) tandis que l'abside a été entièrement construite au XII ${ }^{\mathrm{e}}$ siècle. La suite des travaux envisagés pour les élévations devrait permettre de relever plus précisément les baies qui présentent des différences au nord (étroite avec linteau) et au sud ; de même que les appareils et les mortiers.

2 Le statut de cette église proche de celle d'Igé (paroisse) n'est pas évident à son origine. La multiplication des ouvertures d'accès, au nord et au sud, l'absence d'une porte occidentale au profit d'un bâtiment comme à Uchizy, militent pour un statut particulier. 
INDEX

Mots-clés : chapelle

Index géographique : France/Domange, France/Igé 